\title{
ERBB2 Gene Mutation
}

National Cancer Institute

\section{Source}

National Cancer Institute. ERBB2 Gene Mutation. NCI Thesaurus. Code C96866.

A molecular genetic abnormality indicating the presence of a mutation in the ERBB2 gene on chromosome $17 q 12$. 